\title{
VROU EN AMP EN DIE AMP IN DIE ALGEMEEN
}

Skrywer het as saamroeper van die Afrika-studiekommissie 'n rapport vir die sekretaris van die G.E.S. saamgestel en daarin ook die gegewens verkry van $\mathrm{dr}$. J. D. Vorster (kyk vorige nr. I.d.S.) oor die vrou in die amp verwerk.

Ondertussen het dit duidelik geword dat hierdie aangeleentheid wye kerklike belangstelling geniet en aktueel is ten opsigte van albei rigtings van die mandaat, naamlik die vraagstuk oor die vrou in die amp sowel as die opdrag om vas te stel wat die Nieu-Testamentiese amp karakteriseer. Die sekretaris van die G.E.S. het sub dato 8.2.71 berig dat hy en ds. Bas Nederlof ooreengekom het „that we should use the African report... as a basis for further discussion and comment, and, hopefully, as the body of a unified report..."

Van professor George W. Knight, assistent in praktiese teologie aan die Covenant Theological Seminary, St. Louis, Missouri is ondertussen die volgende kommentaar ontvang:

„The African regional committee has presented an able study report. It has analyzed the mandate carefully, shown the problematics involved in fulfilling such a task, and proceed to accomplish a very significant task for the RES. The study is marked by a forceful cogency based on particular exegesis and a broad Biblical-theological perspective. It sees the issues discussed in their relationship to the over-all view of the church in the New Testament. And it speaks relevantly in interacting with questions of the day, particularly those raised by the report to the last R.E.S. . . I find the report particularly strong in its understanding of the relationship of the special office to the whole church..."

Ten opsigte van paragraaf 1.5 , waar geargumenteer word dat op grond van die verteenwoordigende karakter van die besondere amp, die Vader en Seun (manlik) ook in die manlike verteenwoordig word, skryf prof. Knight:

„I was at first a bit taken back and reactionary... On rereading and reflecting on N.T. data not therein explicitly referred to, I was convinced. But this experience indicated to me that such N.T. data must at least be referred to for the readers' benefit. At the conclusion of the sentence referred to the report should add in parenthesis the following: (cf., e.g., 1 Cor. 11 : 2-16, especially verses 3, 4 and 5)."

In die lig van die geweldige aktualiteit van die vraagstukke en in die lig van die ondervinding van prof. Knight dat sekere aspekte 
behoorlik nagedink en ook beter gegrond kan word, neem ondergetekende vryheid om die stand van die studie so ver dit die Afrika-rapport betref, ook vir ons broeders mee te deel. Dit kan die saak, waarby die hele Gereformeerde wêreld vandag belang het, alleen goed doen wanneer daar opnuut oor die amp diep en radikaal in die lig van die Skrif besin word. Ons sou dit verwelkom indien broeders ons oë kan open vir meer misvattinge, onvoldoende of inkorrekte bewyswoering, ens. Dit is tog belangrik dat iets wat as 'n "Afrika-rapport" bekend staan ook in die streek gekontroleer word.

\section{Die wese van die amp in die Nuwe Testament}

Dit was duidelik uit die rapport van die studiekommissie oor die vrou en die amp voor die G.E.S. van 1968 dat 'n behoorlik omlynde begrip van die bepalende karakter of wese van die amp ontbreek het. Die studiekommissie het die amp probeer vind in die relasie tot die gemeente en dus gelet op ,public functions" (p. 148), „public actions” (p. 147), ,public and private services" ( $p$. 155), ,special place” (p. 146). blote ,function" of selfs enige vergelykbare aktiwiteit met die "ministry of clergyman” (p. 146).

Volgens hierdie horisontale ampsopvatting kom die amp neer op n klerikale betrekking (' $n$ amptenaar van en in die kerk) waaroor die kerklike liggaam beskik. Daarvolgens kan geredeneer word dat die kerk tydens die reformasie een gedragskode gevolg het en dat die kerk in "moderne" tye nuwe praktyke kan beoefen. Hierdie klerikale ampsidee korrespondeer nie met die Gereformeerde Bely. denis en Skrifgegewens nie. Ons vestig aandag op die volgende essensiële karaktertrekke wat die wese van die amp moet bepaal.

\subsection{Die teosentriese karakter:}

Volgens die Skrif staan die gemeente of kerk, universeel en plaaslik na sy onsigbare en sigbare kante (al is daar meningsverskil oor hierdie onderskeiding, vgl. A. D. R. Polman: Woord en Belij. denis II, p. 159) in 'n direkte vertikale verhouding tot God. Die kerk rus op God se verkiesing, roeping, verwerkliking en bewaring (vgl. N.G.B., art. 27-28 en Ileid. Kategismus Sondag 21). Die kerk is tempel en volk van cod (2 Kor. 6 : 16), kudde van (rod (Hand. $20: 28,29)$, huis van God (1 Tim. 3:15). Hiervolgens is elke vorm van horisontalisme as uitgangspunt by die kerk uitgesluit. Die kerk is eenvoudig nie 'n menslik-gebore vereniging of genootskap vir gelykgesinde belange nie. Die uitgangspunt van Harnack word deur die Skrif nie gesteun nie.

Dieselfde teosentriese karakter word ook uitdruklik aan die amp verbind. Dit lê al in die begrip apostel aan wie weer die ouderlinge ten nouste in die gemeente verbind word (Hand. 15: 4, 6, 22, 23). Die apostel van Jesus Christus (Rom. 1 : 1, 2 Kor $1: 1$, Ef. $1: 1$, Kol. $1: 1$, Ef. 3:5, 1 Tess. $2: 6$ ) is ook 'n dienaar (diakonos) van God (2 Kor. 6:4) en van Jesus Christus (Rom 
13: 16). Dit word ook op ander oorgedra (1 Tim. 4:6, 11-16) terwyl daar valse apostels is wat voorgee dat hulle apostels van Christus is (2 Kor. $11: 13)$.

Veral hierdie laaste teks is belangrik. Die ware ampsdracr het meer nodig as om te sê, voor te gee, dat hy 'n dienaar van Christus is. Die ampsbepalende waarmerk, die karakter, is geleë in roeping van God, aanstelling van God, geopenbaarde wil van God (vgl. by Paulus die verdediging van sy amp, gesag wat die Here my gegee het om op te bou, 2 Kor. $13: 10$; Gal. $1: 10,12,15$; Hand. 22: 14 e.v., ens.). Ons kom op roeping as wesenstrek terug.

Volgens die Skrif regeer God sy kerk. Hy versorg sy kerk. Die kerk (as liggaam of as vergadering) kom nooit selfstandig langs God in die regering of versorging van sy kerk te staan nie. Geen kerk of sinode beskik dus oor die amp uit sigself nie. Die amp is instrumenteel, 'n wyse waarop God sy gemeente versorg en regeer. (N.B.: Vgl. Calvyn Kommentaar 1 Pet. $4: 11$, veral slotdeel).

1.2 God het die kerkorganisasie en daamee die ampte gegee:

In hierdie verband is Ef. 4: 11 (vgl. 1 Kor. 12) van besondere belang. In die eerste plek word Christus die subjek van edwken. In die tweede plek is daar nadruk op die sommige en ander. Konkrete persone eerder as abstrakte ampte is gegee. In die derde plek is daar differensiasie in die ampte van Christus gegee. Die dienste laat hulle onderskei. Maar agter Christus is tog ook weer God wat Christus gegee het as Hoof bo alle dinge aan die gemeente (Ef. 1:22, Nederlandse Geloofsbelydenis art. XXXI). Derhalwe sê die Skrif dat God self sommige in die gemeente gedifferensieerde dienste gestel het (etheto) 1 Kor. $12: 28$.

Die kerkorganisasie en ampdifferensiasie het dus nie uit die kerk volgens behoeftes en omstandighede in bepaalde tye opgekom nie. Nee, dit is basies as ' $n$ grondplan van God gegee vir die doel wat God vir die ,gebou" (kerk) gehad het (Ef. 2: 19-22; $4: 12,16$ ). Hoewel die apostelamp in die besondere brief 'n buitengewone plek beklee (Ef. 2: 20), word dit ten opsigte van die eienskap dat dit van God gegee en van God ingestel is in Ef. $4: 11$ en 1 Kor. $12: 28$ met ander dienste gelyk gestel. Dit geld eintlik nie ten opsigte van 'n abstrakte amp as 'n ,pos" of ,posisie” nie, maar eerder ten opsigte van die persone wat God gegee en gestel het in gedifferensieerde dienste met die oog op die gemeente.

1.3 Christus is absoluut en sentraal Iloof en Opsiener van sy gemeente:

Die basiese en sentrale begrippe van die evangelie, naamlik Here-van-sy-koninkryk (heerskappy van die Gesalfde oor sy volk), Messias-en-sy-volk, word in die briewe uitgedruk in die verhouding Christus-en-sy-gemeente, soos die Hoof-en-sy-liggaam. Die gemeente: kan slegs gesien word vanuit die gesigspunt van die allesomvattende heerskappy van haar Hoof (vgl. Ned. Geloofsbel. rt. XXVII en H 
Ridderbos: Paulus, p. 437). Christus gee dus in verskeidenheid gawes, verskillende opdragte. Die feit dat $\mathrm{Hy}$ dit doen, sluit elke sweem van gedagte uit asof dit ,diskriminasie" inhou of ruimte laat $v$ ir individualisme om 'n eie rigting op te gaan (vgl. Ridderbos: a w., p. 440). Die liggaam (gemeente) verklaar juis die klaarblyklike verskille, verskeidenheid en differensiasie (1 Kor. $12: 12-31$ ) en lê nadruk op die gawes, dit wil sê, God het die verskeidenheid in die geheel gewil (vs. 18) en gegee (vs. 28).

Wanneer vandag beweer sou word dat iemand uit die amp geweer is bloot net op grond van destydse sosiale omstandighede, word daarmee tegelyk gesè dat Christus dus wel destyds diskriminasie binne die gemeente as liggaam van Christus toegepas het en Hom ten opsigte van 'n essensiële aspek van die kerkopenbaring deur sosiale omstandighede laat dikteer het. Diskriminasie is egter juis strydig met die nie-diskriminerende karakter van die gemeente in die nuwe testamentiese tyd. Gevolglik kom die vraag na vore of die probleemstelling ten opsigte van die vrou in die amp nie uitgaan van 'n foutiewe aksioma dat nie-konsiderasie vir die amp neerkom op diskriminasie - terwyl die Skrif uitgaan van harmonie tussen verskillende gawes, opdragte, werkinge en eerbedelinge binne dieselfde liggaam van die Hoof Christus. ' $n$ Mens voel die parallel tussen die vrou as die swakkere aan wie die man eer bewys (1 Pet. $3: 7)$ en die swakste lid in die gemeente wat oorvloediger eer ontvang (1 Kor. $12: 22,24$ ); en die verhouding Christus-gemeente, Hoof-liggaam, word so natuurlik normatief vir die twee-eenheid van man en vrou (twee wat een vlees word) gestel (Ef. $5: 22-33$ ). Hierdie korporatiewe aspek in die gemeente en in die eenheid tussen man en vrou, mag nie met 'n individualistiese siening van man en vrou en van die lidmate in die gemeente, weggesyfer word nie. Wanneer Christus slegs sekere manne in bepaalde dienste, met bepaalde gawes en opdragte, sou gee, is dit juis sy gawe aan die hele gemeente - 'n gawe ook aan die manne wat nie tot ampte verkies word nie en aan die vroue. Die verkiesing van broeder $A$ tot $n$ amp is nie diskriminasie teen broeder B wat ,uitgeval" het of suster C wat nie in die verkiesing oorweeg is nie.

\subsection{Christus neem die ampte in diens:}

Art. XXX van die Ned. Geloofsbel. bely inklusief die drie gewone dienste van bedienaars van die Woord, opsieners en diakens. Die Nederlandse Belydenis verbind nog nie eksklusief bepaalde take of dienste aan bepaalde ,ampte" nie. Die differensiasies word egter volgens die beginsels van die belydenis uitgewerk in die Nederlandse Kerkordes sedert dié van Wezel in 1568. (By Calvyn en die Franse kerk het dit al vroeër voorgekom.) Agter die kerkordelike ontwikkeling skuil dus die Konfessie, sodat dit foutief is om te redeneer dat dit hier slegs om 'n ,reformed practice" gaan. Ons beperk ons vir eenvoudiger argumentasie by die drie erkende gewone ampte van art. XXX N.G.B. 
Volgens H. Ridderbos (a.w., p. 426-432) druk die begrip hoof 'n seggenskap, 'n aanvangrelasie, 'n beslote-wees-in, 'n verteenwoordig-word-in-die-ander, 'n vele-in-die-een uit. (Hierdie beginsel moet ook in gedagte gehou word in verband met die man as die hoof van die vrou). Die begrip hoof hou verder in dat die organe waarvan Christus Hom bedien, nie aan Hom gelyk of in sy plek kan tree nie. Hulle kan slegs amp of diens, wees (onderskeie van dié wat voorgee om dit te wees, 2 Kor. $11: 13$ ) wanneer hulle Christus bedien en dien, dit wil sê, gebonde aan sy Woord en Gees optree. Gevolglik sê Calvyn: „Die ampsdraer is slegs ' $n$ instrument in Sy hand. En ' $n$ instrument hoef niks anders te doen as om hom te onderwerp aan die een wat hom hanteer" (L. Goumaz: Het ambt bij Calvijn, p. 16).

Die Reformasie het juis die Skrif sy uitgangspunt vir die ampsleer gemaak, terwyl Rome die Kerk die ampte laat bepaal het. H. Ridderbos (a.w., p. 490) toon dat sodra die Skrif losgelaat word, die liberale kerkbeskouing van Sohm en Harnack moet volg, wat sy uitgangspunt neem in die religieuse individu en die persoonlik. pneumatiese betrekking tussen Christus en die gelowige individu. Daar sal baie krities besin moet word of die vraagstukke rondom die vrou in die amp en die bevoegdhede van sekere ampsdraers kragtens persoonlike charismata, nie grootliks neig om hulle uitgangspunt in die individu te neem nie.

\subsection{Goddelike sanksie verleen aan die amp ' $n$ representatiewe} karakter:

Calvyn het al in Ou en Nuwe Testament 'n gemeenskaplike karaktertrek van alle ampte opgemerk, naamlik die kenmerk van goddelike sanksie wanneer "God de taak en macht om het gezag en macht uit te oefenen verleent. Deze macht herkent men daarin dat ze door God geschonken is tot heil van de kerk" (2 Kor. 10:8) (Goumaz: a.w., p. 40-41). Hierdie goddelike sanksie en saakopdrag vorm dus in die O.T. en N.T. 'n kenmerk van die diens van ' $n$ persoon in 'n amp van die Here. Die sanksie geld dus nie net ten opsigte van die abstrakte begrip ,amp", byvoorbeeld ,amp" van koning, nie. Nee, die sanksie geld die persoon as koning. Paulus as apostel, Timotheus as evangelis.

Volgens die Skrif handel God (en Christus) deur die ampsdraers as sy organe, diensknegte, slawe, herders. Daarom kom die genitivus van God of van Jesus Christus dikwels voor by diakonos, leitourgos, hupêretês, ens. Vanuit die goddelike sanksie en die amp as blote instrument van God, vloei dus die representatiewe karakter van sekere dienste voort. Waar die besondere amp bedien word, is God en Christus self in die bediening aanwesig. Hierdie gewigtige feit is reeds duidelik uit die sleutelmag (Matt. $16: 19,18: 18$, Joh. $20: 21,21: 15-17,22)$. Die dienskneg is net 'n tolk (1 Kor. $3: 7$ ), 'n medewerker (vs. 9) wat op 'n gelegde fondament alleen kan voortbou (vs. 9-13, vgl. Ef. $2: 20$ ). Die verteenwoordigende 
karakter is baie sterk aanwesig in die apostolaat (Gal. 4:14, 2 Kor $5: 20$ ). Dit word egter ook na ander dienste oorgedra en die agting van die gemeente geëis juis ter wille van hulle werk ( 1 Tess. 5 : 12-14, vgl. Hand. $15: 23$ waar die gesag van apostels, ouderlinge en die Heilige Gees verbind is). Dit spreek vanself dat die opvolgers van die apostels wat dieselfde Woord bedien (1 Tim. $4: 13,14$; 2 Tim. $3: 10 \mathrm{v}$; 1 Pet. $4: 11)$ Christus op dieselfde wyse verteenwoordig (vgl. 2 Tim. 2 : 1, 2, 12, 24). Rome se leer oor die amp gaan verkeerd wanneer dit aan die verteenwoordigende karakter (gebonde aan die Woord en Gees) 'n plaasvervangende (vir God of Christus op aarde) karakter verleen.

Uit hierdie verteenwoordigende karaktertrek van die amp spreek vanself dat die Sender moet aanwys wie hom sal verteenwoordig. (Kyk hiervoor ook by roeping). In die tweede plek is dit vanselfsprekend om te verwag dat die Vader en die Seun (manlik) in die gewone orde ook deur die manlike (manne of broeders) verteenwoordig sal word. So stam die woord presbuteros al uit die $\mathrm{Ou}$ Testament met 'n manlike konotasie (Hand. $11: 30,14: 23,15: 2$. $4,6,22,23 ; 16: 4,20: 17$ ). Broeders (Hand. $2: 37,3: 22,7: 37$, $6: 3,11: 29,15: 3,22,23,33,36$ ) of manne (Hand. $2: 29,6: 3$ ) vorm die adres van die gemeente of van die voorstanders (sogenaamde "ampsdraers") van die gemeente. Wat ons onder ,amp" verstaan (,Narrow sense of the ministry of clergyman, elder and deacon", deputate-rapport G.E.S. '68) loop in die Nuwe Testament in die bedding van adelphos of andres. Wie later diakens genoem word, word in die Skrif aanvanklik net manne genoem (Hand. $6: 3$ ).

\subsection{Christus gebruik die amp met die oog op die gemeente:}

Die ,amp" of ,ampsdraer" is nie doel op sigself nie maar is op die gemeente gerig, selfs by verskillende dienste. Hand. $6: 2$ toon dat die diens van die sewe van die apostelamp gedifferensieer het. Die sewe moes die tafels bedien terwyl die apostels slegs met gebedebediening en Woordbediening sou voortgaan (vgl. Hand. 2 : $41-45 ; 4: 32-35 ; 6: 2-4$ ). Dit gaan om die gemeente. Die opbou van gemeentes (Hand. $9: 31$ ) word genoem by die roeping van Paulus. Die opbou van die gemeente as liggaam van Christus (toerus van die heiliges vir hulle ergon diakonias) volg in Ef. 4: 12 onmiddellik nadat die goddelike gawe van verskillende dienste aangetoon is. In 1 Kor. 12 : 28 word met nadruk die differensiasie van dienste beklemtoon en gesê dat God dienste (of liewer, mense met diensopdragte) in die gemeente gestel het. In die diensomlyning vir Timotheus (2 Tim. $4: 2$ ) lè die Skrif nadruk op die bediening aan die individu (die mens van God, 2 Tim. $3: 17$ ). - Toerusting van die individu kom neer op opbouing van die gemeente. Indien ons onder dienswerk (Ef. $4: 12$ ) die sogenaamde ,amp van die gelowige" (vgl. roeping tot elke goeie werk, 1 Tim. $3: 17$, goeie werke, Matt. 5 : 16) verstaan, kan afgelei word dat die diensbaarheid van die besondere ampte tot die amp van die gelowiges, indi- 
vidueel en korporatief, die wese van die besondere ampte medebepaal (vgl. 1 Pet. $4: 10)$.

Hieruit volg noodwendig dat die amp nic verleen word met die oog op die verwesenliking van die een wat die amp ontvang nie. Die $a m p$ word nooit verleen met die oog op die ampsdraer nie. Die amp word nie verleen om ,aktiwitente" of privileges vir die ,, iraer" van die amp te ontsluit nie.

Sodra die besondere ampte egter as 'n geprevilegeerde kategorie binne die gemeente gesien word (vgl. Rome, kollegialisme, ens.), ontwikkel ' $n$ klerikalistiese kerkaktiwiteit. Indien sekere kerklike aktiwiteite tot geprevilegeerde anıpsdraers beperk is, beteken dit dat elkeen, ook manslidmate, wat nie tot ' $n$ besondere amp verkies word nie, ongelyk of gesubordineer is aan sy broeder wat wel 'n besondere amp beklee. Die blote feit dat hy en sy broeder tot dieselfde sekse behoort. maak nie sy posisic ten opsigte van die .amp" of .,ampsdraer" anders as dié van 'n vrou wat nie vir die bekleding met ' $n$ amp oorweeg is nie. Gevolglik moet benadruk word dat dit in die kerk van Christus eintlik gaan om die dienswerk, amp van elke gelowige, die werking vall elke lid van die liggaan van Jesus Christus. In die rapport oor die vrou in die amp voor die G.E.S. in 1968 is telkens aktiwiteite wat hiordie dienswerk as die amp van gelowige kwalifiseer, aangedui as grond vir die toelating tot die besondere ampte. Logies beteken dit dat die besondere anp dan eintlik 'n doelpunt of spesialisasie van die amp van gelowige in plaas van 'n hulpmiddel vir Christus tot vervolmaking van die amp van die gelowige beskou word.

\subsection{Die Skrif het sy heel besondere konnotasie vir die begrip amp:}

Vandag beteken die begrip „amp" in ons gesekulariseerde Westerse denke min of meer 'n abstrakte waardigheid waarmee iemand beklee word en waardeur hy sekere geprevilegeerde funksies kan vervul. In sekulêre organisasies impliseer "amp" selfstandige of gedelegeerde bevoegdhede. Die ampsdraer kan kragtens die ,amp" waarmee hy (deur ander) beklee is, funksies uitoefen as koning, regter, direkteur, voorsitter, sekretaris minister, predikant, ouderling, ens., - funksies wat 'n gewone lid nie kan uitoefen nie. Gevolglik het die begrip ,amp" die smaak dat die organisasie of die persone in die organisasie, aan die persoon van die ,ampsdraer" onderworpe raak. Sodoende bring die ,amp" status vir die bekleder mee. Deur die status ontstaan 'n sekere mate van ,inequality" tussen die bekleders van die amp en diegene wat nie die amp beklee nie. Vanuit hierdie sekulêre oogpunt kan dus gevra word: Waarom kan een ouderling die seën uitspreek en 'n ander nie? Ten grondslag van die problematiek lê dan die abstraksie ,anıp", 'n verselfstandigde begrip.

Ons moet nou egier met groot nadruk daarop wys dat die begrip .. (Imp", as aanduiding vir die waardigheid wat op iemand gelê word - en selfs die begrip, ,ampisiluer" waarmee die gemeenskaplike 
waardigheid aangedui is (wat ewe goed vir 'n predikant, ouderling of diaken geld), nie aan die Skrif ontleen is nie. In die problematiek van hierdie studie kan 'n mens met reg vra of die begrippe "amp" en „ampsdraer" ooit die skriftuurlike konnotasie kan weergee en of hierdie onskriftuurlike abstraksies nie grootliks hierdie problematiek veroorsaak het nie.

In die eerste plek moet ons sè dat die Skrif nie weet van iemand wat tot 'n abstrakte ,amp" gestel is nie - maar iemand is bepaaldelik tot apostel, evangelis, profeet, diaken, herder, ouderling, opsiener, helper, of iets dergeliks geroep. Dit impliseer dat die terminus technicus elke amp omskryf - sodat daar nie 'n gemeenskaplike begrip ,amp" as waardigheid kristalliseer nie.

In die tweede plek sê prof. Herman Ridderbos dat Paulus ons begrip "amp" vernaamlik weergee met gawes (charismata) en dienste (diakoniai). Hy gee talle Skrifplase (a.w., p. 492). Die een woord beskryf ,amp" van die kant van God en die ander die „amp" van die kant van die gemeente. Daarbenewens kom die begrippe werkinge, werk, bediening, beheer en dienswerk voor. Charisma karakteriseer wat Christus deur sy Gees in die gemeente doen Diakonia kenskets die wyse waarop dit in die gemeente funksioneer. Ridderbos wys dat by die charismata wat bepaalde ampte aandui, nie die ,ambtelijk-institutionele als zodanig, maar de inhoudelijke betekenis van het ambt op de voorgrond word gebracht". Daar is egter geen teenstelling tussen die charismatiese en institutionele nie (a.w., p. 496).

In die Roomse ampsleer staan die institusionele voorop. Omdat iemand met ' $n$ amp beklee is, kan hy sekere magte uitoefen. In die Skrif word egter van die inhoud uitgegaan. Die vraag is nie primêr na wat die amp op sigself is nie, maar na wat Christus met die bepaalde diens doen. So is die amp self charisma (Ridderbos: a.w., p. 498). Die amp is 'n diens en 'n gawe, 'n kwaliteit eerder as 'n formele waardigheid. Die mate van waardigheid wat aan die amp verbind word, vloei juis uit die kwaliteit van die diens voort (1 Tess. $5: 12,13$ ) — in plaas van dat die werk uit die waardigheid voortvloei.

Daar moet dus aangetoon word dat 'n besondere werk of diakonia as 'n gawe aan sy gemeente gegee is in die sin wat ons Rom. 12 : 4-8 saam met 1 Kor. $12: 27-29$ en Ef. $4: 11,12,15,16$ moet verstaan. Dan herhaal ons weer: hierdie dienste as gawes is nie los te maak van die bepaalde persone wat God gestel (1 Kor. 12 : 28) of gegee het (Ef. $4: 11$ ) in die bepaalde diens nie. Uit Rom. 12 : 6 en 1 Kor. 12 : 30 is duidelik dat die genadegawes (charismata) aan die hele gemeente gegee word. Een van die charismata is ook elke besondere amp. Die amp is charisma, maar nie alle charismata is ampte nie. (Daarbenewens het die gelowige en dus ook die ,ampsdraer" gawes nodig, 1 Kor. $7: 7$, Ef. $4: 7,1$ Tim. $4: 14$, 1 Pet. $4: 10$ ).

Ons kan dus sê dat die genadegawes vir die besondere dienste by meer lidmate as net die betrokke „ampsdraers" aanwesig kan en 
sal wees. Die beslissende vraag is dus andermaal weer nie of iemand as lidmaat die gawe vir 'n besondere ,amp" ontvang het nie maar wel of ' $n$ bepaalde persoon met bepaalde gawes in ' $n$ bepaalde diens as 'n gawe aan die gemeente gegee is. Om oorvloedig duidelik te wees: Die Skrif sê dat vroue ook besondere charismata ontvang het en dat vroue as vroue charismata in die kerk van die Here was, maar daar is nie die minste bewys of getuienis dat vroue in die besondere charismata van opsieners- of diakendienste aan die gemeente gegee is nie.

1.8 Roeping is ' $n$ bepalende karaktertrek vir die besondere dienste:

'n Groot deel van die voorafgaande betoog kom neer op die saak van roeping.

1.8.1 Onder roeping kom allereers die inwendige roeping ter sprake. Dit is 'n regstreekse roeping van die Here deur sy Heilige Gees (Hand $13: 2 ; 20: 28 ; 22: 10$. ens.) vir 'n bepaalde werk of diens (ibid.) van 'n bepaalde persoon (vgl. Hand. $1: 24 ; 13: 2$ ). Hieronder kan die begeerte tot $n$ besondere diens ( 1 Tim. $3: 1$ ), die toerusting vir 'n diens ( 1 Tim. $4: 14$ ) ens., verstaan word

1.8.2 Die roeping geskied egter nie meer regstreeks soos by die dissipels en Paulus as ontydig-gebore apostel nic, maar middellik deur die gemeente. Die roeping deur middel van die gemeente dien dus as bevestiging van die innerlike roeping (Hand. $1: 26 ; 6: 5 ; 13: 3 ; 14: 23$; Titus $1: 5$ ). Die uitwendige roeping is egter sekondér ten opsigte van die inwendige roeping van God (vlg., die eerste vraag by die bevestigingsformulier).

\subsection{Roeping lei na bevestiging}

'n Bepalende karaktertrek van elke sogenaamde besondere "amp" is ongetwyfeld die openbare bevestiging in die gemeente. In Hand. $1: 26$ beteken sugkatepsêfisthe (,kies") volgens Grosheide "instemming met die loting en aanvaarding van die uitslag vir eie rekening". In Hand. 6 - 5 word "uitkies", ,afsonder" (eklegw) gebruik, maar in $6: 6$ stel die gemeente die gevraagde manne (vs. 3) voor die apostels. Die apostels lé hulle die hande op as teken van erkenning en oordrag van genade. Die feit dat dit eers na gebed plaasvind, toon duidelik dat die sigbare handeling sy dieper sin alleen vind wanneer God op die gebede saamwerk. Die handeling van handoplegging by die instelling van persone in die besondere amp van ouderling kom meermale voor (1 Tim. 4:14), selfs met die waarskuwing om daarmee versigtig te wees (1 Tim. 5:22). Die handoplegging begelei soms die gawe van die Heilige Gees (Hand. $8: 17 ; 9: 17$ ). Bouma sien daarin dus 'n simboliese handeling wat by die ampsbevestiging ' $n$ oordrag van God simboliseer (2 Tim. 
1 : 6). Die werkwoord Cheirotonew vir ,.kies" in Hand. $14: 23$ laat die betrokkenheid van die gemeente uitkom, terwyl daar selfs 'n sterk moontlikheid is dat die reg van die vers op die ouderlinge slaan (of anders op die gemeente met verkose ouderlinge) wat ná gebed en vas aan die Here opgedra is.

Uit die gegewens kan afgelei word dat die institutionele handelinge ten opsigte van bevestiging in die ampte (dié van tafelbedienaars in Hand. 6,, dié van ouderlinge en dié van die evangelis, Timotheus) bedoel om die primêre goddelike sanksie en volmag tot 'n bepaalde diens openlik te erken en te bevestiging.

\subsection{Die groot verskeidenheid van gawes, dienste, bediening ens.}

$H$. Ridderbos het 'n magdom Nieu-Testamentiese getuienis, soos dit by Paulus voorkom, saamgevat en aangetoon ' $n$..grote verscheidenheid in gaven en diensten ... die echter in de eenheid van het lichaam en in het algemeen welzijn daarvan haar samenstemming vinden" (a.w., p. 499).

1.10.1 In verband met dic Nieu-Testamentiese getuicnis oor die buitengewone ampte, apostels, profete. evangeliste, buitengewone kragte, tongespraak, verwys ons na prof. Herman Ridderbos: Paulus. p. $499-522$.

1.10.2 In dieselfde gedeelte gce Ridderbos baie gegewens oor die gewone dienste van leraars, opsieners, ouderlinge, diakens en hy gee afsonderlik aandag aan die rol van die vroue in die opbou en toerusting van die gemeente.

1.10.2.1 Ons kan kort gaan en dadelik die afleiding maak dat die ouderlinge ook die opsieners was (Hand. $20: 17,18$ ). Binne hierdie amp het daar egter differensiasie ingetree tussen dié wat regeer deur te arbei in woord en leer en dié wat net regeer. „Opsiener" beskryf dus eintlik die diens van die ouderling. Die differensiasie kan saamgevaí word as dié tussen opsieners wat ook leraars is en die ander. Die leraars word met ' $n$ bepaalde noemer (ten derde) in 1 Kor. $12: 28$ en in Ef. $4: 11$ in een asem met herders genoem. Die begrip leraar kom uit die O.T., rus op die apostels (1 Tim. 2:7) en gaan oor op hulle opvolgers en die gemeente, Rom. $12: 7,1$ Kor. $14: 26$ (vgl. opdrag tot lering aan Timotheus). Tog vorm die leraars 'n onderskeie groep in die gemeente ( 1 Kor. $12: 28$; Ef. $4: 11$ ) wat op onderhoud (Gal. 6:6) en erkenning ( 1 Tim. $5: 17$ ) geregtig is. Die bekwaamheid om te onderrig word van die opsieners en ouderlinge gevra (1 Tim. $3 ; 5: 17 ; 2$ Tim. $2: 2$; Tit. $1: 9)$. Aan die vroue word hierdie diens egter uitdruklik ontsê (1 Kor. $14: 34 ; 1 \mathrm{Tim} .2: 11,12$ ). Die leraars is gebonde aan die oordra van die apostoliese tradisie (Rom. 6 : 17; Gal. $1: 12$; 2 Tess. 2 : 15; Kol. $2: 6,7$; 1 Kor. $4: 17 ; 2$ Tim. $2: 2 ; 3: 14$ ) wat die evangelie is (Gal. $1: 12$; Kol. $1: 28 ; 3 ; 16)$.

Daar is meriete om selfs onder die leraars weer dié wat leraars 
oplei te onderskei van die wat in de gemeente leer on onderrig gee (my ware kind, 1 Tm. 1: 1, 3, 18: 2 Tim. 1:2, 6, 1:3, vgl. 2 : 1; vir leraurs vgl. ook Calvyn Kommentare, 1 Pet. 4: 11 ; 1 Tim. 3: 14; Titus 1: 3; my seun, 1 Pet. 5: 14.

1.10.2.2 Die Skrifgegewens in die voorgaande paragraaf dui reeds op die noue verwantskap tussen begrippe leraar en herder. Hierdic dienste rus in Christus, die Herder en Opsiener (1 Pet. 2 : 25) sodat die ouderlinge ook herders en opsieners van die kudde is (Hand 20: 28; 1 Pet. 5 : 12). Aan die ouderlinge, opsieners, herders, is die algemene leiding van die gemecule opgedra (Hand $11: 30 ; 1$ Tim. 5: 17). Die woord pro-histumenos (Rom. 12:8) is in 1 Tess. $5: 12$ verbind aan .evermalan"; in Hebr. 13 : 7 aan ,verkondiging van die Woord"; en 1 Tim. $3: 4$, verbind aan ,eie huisbestuur", wat ook hulle taak in die gemeente is. 1 Tim. 5: 17 wys sterk in die rigting van leidiny, regeer, opsig, dieselfde posisie in die gemeente wat die man as voorganger in die huis, 1 Tim, $2: 8,12$; Ef. $5: 23 ; 1$ I'et 3 : 1, beklee. Soos van die vrou 'n sekere onderdanigheid aan die man in die huis getis word, word onderworpenheid van die gemeente aan dic voorgangers voorgeskryf (1 Kor. 16: 16; 1 Tess. 5 : 12). Die ouderlinge word apokalipties op trone gesien (Openb. 4 : 4); die apostel is 'n mede-ouderling wat as herder toesig oor die kudde hou (1 Pet. $5: 1,2$ ); die ouderlingr verwys na die gemeente as sy kinders (2 Joh. 1). Apostels, leraars en opsieners oefen dus die diens van tocsig, leiding, regering, voorganger, uit - terwyl nie elke ouderling in die besondere sin leraar is nie.

1.10.2.3 Dit moet genoem word dat in die Nuwe Testament verskillende dienste en gawes soms by dieselfde persoon voorkom. Dit moet dan egter sterk in gedagte gehou word dat hierdie dienste en gawes nie as 'n ekstra by die gemeente bygekom het nie, maar juis uit die gemeente as die liggaam van Christus gegroei het (vgl. H. Ridderbos: a.w., p. 501). Die interpretasie van ,amp" en ,ampsdraer" as 'n antitese met lidmaat of gemeente (vgl. die „clerus en leke" by Rome) - of "amp" of ,ampsdraer" as "n noemer vir verskillende dienste en gawes teenoor lidmate, kom nie in die Skrif voor nie. Selfs by 'n algemene aanduiding soos prohistamenoi is die geintegreerde verweefdheid van die gawes en dienste met en die funksie van voorgaan in die gemeente uitgedruk. Hierdie woord omvat dan ook kragtens die kwalitatiewe aanduiding van die diens die opsieners en nie per se diakens nie. Die Skrif spreek onderskeidend van opsieners en diakens (Ef. 1:1; 1 Tim. 3). Die Skrif praat duidelik onderskeidend van dienste. - Tog is dit nie so dat vir elke diens ' $n$ afsonderlike besondere "amp" ingestel moet word nie. Nie die bekleder van die amp nie, maar die inhoud van die diens kwalifiseer die verskeidenheid. Indien dus verskillende dienste aan verskillende persone toegese word, 
sal elke persoon hom moet bepaal by die diens aan hom toegewys. - Omstandighede kan niemand 'n besondere diens tydelik oplê nie. Dit lê in die aard van die diens dat iemand daarin gestel is - of hy is nie.

1.10.2.4 Op grond van voorgaande paragrawe waarin duidelik geword het dat die diens van leraar (didaskalos) en herder (poimên) nou verwant is, kan afgelei word dat dit moeilik is om op Skrifgronde waterdigte onderskeidinge te maak. Indien op die beginsels van differensiasie in ' $n$ hedendaagse kerkorganisasie 'n duidelike onderskeiding gemaak word tussen opsieners wat meer in besonder met die Woord en gebede leer en opsieners wat met die Woord en gebede meer in besonder regeer, dan is daardie onderskeiding geregverdig. Waar die onderskeiding geld, sou enige optrede wat weer tot uitwissing van die differensiasie kan lei, onverantwoord wees. Daar word dienste onderskei deur die kriteria van lering of regering (in die $\sin$ van huisbestuur) aan te lê — of daar moet van net een opsienersamp aan wie verskillende dienste toegewys is, uitgegaan word. Laasgenoemde oplossing lyk nog minder aanneemlik, wanneer in gedagte gehou word dat saam met die ouderling-opsieners waarvan ons in die Skrif lees, daar naas-aan (buitengewoon) nog apostels (Paulus, Johannes, e.a.) as „opsieners" werksaam was. Die briewe aan Timotheus (en Titus) toon dat 'n ,evangelis" soos Timotheus die apostoliese dienste (insluitende die lering) moes oorneem ( 2 Tim. $3: 10-4: 5$ ) omdat die apostel weggaan (4:6). Sy opdrag tot lering strek selfs weer oor ander manne wat self moet leer (2 Tim. 2: 2; 1 Tim. 1 : 7, oor valse leraars). Timotheus moet ' $n$ besondere leerdiens verrig $(4: 11-16 ; 5: 13)$. Hy moet as primus inter pares leiding neem, veral wanneer 'n ouderling beskuldig word (5 : 19). Die loslating van hierdie gelykheidsbeginsel in die differensiasie het tog onteenseglik gelei tot die intrede van die biskop.

Daar kan dus gesondig word na links en na regs - deur onderbeklemtoning en deur oorbeklemtoning van die differensiasie.

1.10.3 Oor die amp van die diakens word in Gereformeerde kringe rondgetas. Die probleem is dat die term diakonos eerder vir elke diens as 'n terminus technicus vir ' $n$ besondere diens in die Skrif gebruik word. Tog is daar sterk aanduiding in Fil. $1: 1$ en 1 Tim. $3: 1,8$ dat teen die einde van Paulus se bediening die naam wel aan 'n bepaalde diens, onderskeie van die opsieners, begin kleef het. Hierdie getuienis, sowel as die tradisie dat die diens ooreenkom met die diens van die sewe (Hand. $21: 8$ ) in Hand. 6, word bevestig deur die oudste kerkgeskiedenis. Die feit dat die kerk van Rome vir eeue met sewe diakens volstaan het en eerder hulp-diakens as meer diakens bygeroep het, toon ' $n$ direkte verband met die sewe van Hand. 6. (Vgl. hier I.d.S., nr. 9 (Feb.-Maart 1969), 
B. Spoelstra: Geskiedents van die Diakenamp tot voor die reformasie; A. J. du Plessis: Die diens van die Diakens: 'n eksegetiese en praktiestoepassende verkenning; J. C. Coetzee: Stoflike versorging in die N.T.-kerk - waarheen lei dit ons in ondersoek na die diakenamp?).

1.10.3.1 Die werklike diens van diakens word in die Gereformeerde Kerke verbind a an bediening van die armes en ellendi. ges. Wie na die bevestigingsformulier luister en die Gereformeerde tradisic nagaan, merk op dat die diens feitlik daar beperk word. Die bevestigingsformulier substitueer feitlik net so die begrip armes vir die tafels in Hand. 6 . Dit moet tot foutiewe resultate lei, omdat daar geen afdoende bewys is dat die diakonein trapedsais (vs. 2) slegs op armsorg geslaan het nie. In die lig van die destydse liefdesmaaltye en uitsprake soos Hand. $2: 44-46,5: 34,35$ en selfs omdat juis weduwees (waarskynlik armes) oorgeslaan is terwyl ander versorg is (Hand. 6:1), moet hierdie diens waarskynlik breër vertolk word. Dit uas ' diens van versorging van die tafels met stoflike middele.

1.10.3.2 Kragtens die Skrifbeginsels wat die intieme verband tussen enige diens en die gemeente, veral die opbouing van die gemeente (Ef. $4: 11-16,1$ Kor. 12:27-31), blootlê, moet die diakendiens waarskynlik meer gesien word in sy betrokkenheid op die gemeente as 'n lewende gemeenskap, wat die liggaam van Christus is. Die gemeenskap (koinonia) word reg aan die begin (Hand. $2: 42$ ) 'n suil, 'n wesenstrek van die kerk. Dit is logies dat ' $n$ bepaalde diens daarvoor gestel word. Die aktiefkonkrete konnotasie van koinonia plaas die nadruk op ,met iemand (en mekaar) deel hê aan jets, 'n aandeel neem aan iets en deelname gee aan iets". In die gemeente van Christus as sy liggaam, bring die koinonia dus die betrokkenheid van die lidmate afsonderlik en gesamentlik met mekaar in Christus na vore

1.10.3.3 Die Joodse armsorg deur middel van aalmoese was enersyds verplig met tempelbelasting en andersyds 'n vrywillige gawe van individu tot individu. Onmiddellik na die uitstorting van die Heilige Gees verdwyn die onderskeiding tussen arm en bemiddeld (Hand. 4:34a) en gemeentelike versorging tree na vore, versorging kragtens en binne die gemeenskap van die heiliges, sowel in die plaaslike gemeente as van een gemeente tot 'n ander (Hand. $2: 42-45 ; 4: 32-34$; Rom. 12:13; Rom. 15:25-31; 1 Kor $16: 1-4 ; 2$ Kor. 8 en 9; Gal. $2: 9-10$ ). Paulus sê uit die geloofsgemeenskap vloei die gemeenskap in die stoflike dinge (Rom. 15:26, 27).

1.10.3.4 Bogenoemde gemeenskapsoefening is binne die gemeente gebind aan die dienste van die sewe (Hand. 6) maar selfs waar dit van gemeentes na die kerk van Jerusalem gaan, word dienaars, afgesonderde gestuurdes, daaraan verbind - persone 
wat deur die kerloe (meervoud) aangewys is en in bepaalde opdrag selfs brieue ointvang het (1 Kor. 16:3, Hand. $11: 30$. 2 Kor. $8: 6,19-24)$.

1.10.3.5 Daar is sterk getuienis dat hierdie vorm van gemeenskap ook gesien moet word in die gemeenskaplike versorging van die leraars (Fil. 4: 10-20, Gal. 6:6). Wanneer Gal. 6: 6 vergelyk word met Rom. $15: 26,27$ tree 'n interessante parallel in die gemeenskapsbclowing en basies eintlik dieselfde gemeen. skapsbeginsel na vore (vgl. ook (ial. 6: 7 met 2 Kor. 9: 6). In die oudste geskicdonis onmiddellik ná die apostels was die diakens stecds by beheer van kerkgoedere sowel as die sogenaamde armversorging betrek. Armversorging word dus ook eintlik van sy konnotasie ten opsigte van 'n individu ontdaan en opgelos in 'n nuwe liefdesgemeenskap waar Christus instrumenteel versorg

1.10.3.6 Hierdie diens is in die Skrif en in die oudste kerkgeskiedenis onderskeie van dié van die opsieners. Waar in laasgenoemde diens die kerugma geilra word deur die bediening van Woord en Gees, word in die diakendiens die kerugma gedra deur die bediening met gawes uit die natuurlike lewe. Daar is ' $n$ heerlike korrelasie in Christus tussen die natuurlike en geestelike (Rom. 12:8, 13; $14: 17-15: 7,24,25-32$, ens.).

\section{Die diens van die vroue}

2.1 Prof. Herman Ridderbos (Paulus, p. 514 e.v.) vind dat Paulus dieselfde twee beginsels vir die huwelik en die gemeente voorskryf. In die eerste plek is die vrou as 'n deelgenoot in Christus colkome gelyk aan die man (gelyk selfs in die sin van eners, geen onderskeid, Gal. 3 : 28; Kol. $3: 11$, vgl. 1 Kor. 11: 11, 12). Aan die ander kant hef die gemeenskap in Christus nie die natuurlike onderskeid (verskil, differensiasie) en die leiding-gewende posisie ran die man ten opsigte van die vrou op nie.

Die eerste beginsel het destyds 'n omwenteling in die posisie van die vrou meegebring, vgl. plek van vroue in die groete Rom. 16, gelyke gawes van profesie 1 Kor. $11: 5$, medewerkers Hand. $18: 2$, Rom $16: 3,6,12$; Fil. $4: 3$ ).

Die beginsel dat die vrou aan die man gelyk is in Christus en dat die vroue so aktief in die arbeid van die apostels en binne die gemeentes betrek is (vgl. ook 1 Kor. $11: 5$ v:; 1 Kor. $14: 12,23$, 26, 31, 34; Ef. 4 : 12; Rom. 12 : 1; 1 Tim. $2: 1 ; 3: 11$; Gal. 3 : 28; Titus $2: 3$ ) bewys dat die vrou nie minderwaardig ten opsigte van die man is of ' $n$ mindere status as die man in Christus beklee nie. Dienste van vroue word ten volle erken en vermeld. Hierdie Skrifgedeeltes gee egter geen aanduiding dat hulle in een van die voormelde besondere dienste werksaam was nie. Hulle was egter nie daarom tweedeklas lidmate nie. Hulle is nie uitgeskakel uit die gemeenteprogram nie. Wie dit as vernedering vir die vrou vertolk, 
moet eers aantoon dat diens in die besondere ampte in spesiale kategorie (clerus?) in die gemeente verteenwoordig en dat deelname daaraan $n$ vertikale verheffing aan die deelnemers bied.

2.2 Naas die duidelike vroue-aktiwiteit on diens in die gemeentes is daar ook aanduidinge dat sekere vroue bepaalde dienste verrig het en bepaalde deugde besit of verwerf het (Fèbe, Rom. 16:1). Ridderbos rangskik dit onder die charismata van hulpbetoon en diene (Rom. 12: 7-8; 1 Kor. 12: 28). Hy meen daar kan nie uit hierdie teks ,stellig" gokonkluderer word dat Fibe tot die ,omptelike" diens van diaken toegelaat is nic. Net so is dif nie duidelik of 1 Tim. 3 : 11 vroue naas die opsiencrs en diakens dan wel die vroue van die diakens aandui nie (vgl. Ridderbos: a.w., p. 515, voetnoot). Dit is egter ongeoorloof (veral ten opsigte van die teosentriese en verteenwoordigende karakter van besondere ample) on saam met Ridderbos (a.w., p. 515) sonder meer te konkludeer dat daar by Fèbe, geen enkel principieel verschil met het bekleden van zulk een dienst ambtelijk aangesteld zijn door de gemeente" aan te dui is nie. Nie die gemeente nie, maar Christus moet die subjek wees wat in 'n bepaalde besondere ,amp" aanstel. Daarbenewens is nie bewys dat Febe iets anders gedoen het as wat elke gelowige geroep is om in die liggaam van Christus te verrig nie. Die beoefening van die dienste deur vroue (vgl. Rom. 12:4-7), selfs al sou die dienste van opsiener of diaken dit in die gemeente as voorganger lei, bewys nog nie in die $\sin$ van Ef. $4: 11$ en 1 Kor. $12: 28$ dat God vroue gestel of gegee het as opsiener en diaken nie. Medewerkers van Paulus het nie apostels (in dic besondere sin van die woord) geword nie. Ewe so is Ridderbos se onderskeidinge van „,niet-ambtelijke charisma” en „geordende ambt” (a.w., p. 516) nie maklik uit die Skrif te begryp nie.

Weliswaar bring hy met die argument op grond van 1 Tim. 5 : 9 e.v. na vore dat daar 'n ,geordende taak voor weduwen in de gemeente en van een bediening of ambt, waartoe sommigen van haar wel, anderen niel moesten worden loegelaten" was (t.a.p.). Indien uitgegaan word van die veronderstelling dat enige geordende diens in die gemeente ,amptelik" moet wees, en dat daar slegs drie vorme van ,amptelike" diens kan wees, naamlik predikant, ouderling en diaken - worú hierdie weduwees as "hulp-diakens" beskou (vgl. Calvyn: Institusie IV, iii, 9 en xiii, 19; Konvent van Wezel, 1568, ens.). Die vraag is egter: warom moct derglike dienste so aangeskakel word - aangesien daar seker naas die diens van opsieners en dié van diakens ook plek is vir ander georganiseerde en geordende dienste om byvoorbeeld koster, voorsitter, skriba, katkisasie-hulpkragte, pleegsorg (indien nodig) ens., te noem.

Dit wys weer dat probleme ontstaan wanneer ons met die abstrakte noemer ,amp" en ,amptelik" opereer, losgemaak van die bekleder daarvan en losgedink van dic bepaalde diakonia, naamlik die van ouderling (lerend of regerend) of diaken.

2.3 Ridderbos gee toe dat die Skrif "bepaalde beperkingen" 
lê op die vrou se optrede in die gemeentevergadering. Uit 1 Kor. $14: 36$ is duidelik dat vroue wel in Korinthe hulle veroorloof het om in die gemeentevergadering te spreek. Dit sny reeds die gedagte af dat die apostel dit afkeur omdat dit in daardie tyd nie gebruiklik was nie (vgl. daarteenoor Deputate-rapport, G.E.S. 1968, p. 147: „at the time and in the circumstances... public actions on the part of the woman were considered indecent"). Dit was in Korinthe wel toegelaat. Daarom moet die apostel dit juis korrigeer. Hy korrigeer dit ook nie op bloot tradisionele gesag nie. Hy beroep hom op die wet en bevele van die Here ( 1 Kor. $14: 34,37$; 1 Tim. 2 : 8-15). Paulus lê dus die swyggebod neer en veroordeel die praktyk in Korinthe in die lig van God se openbaring in die wet en nie omdat hy hom akkommodeer aan bestaande gebruike en opvattinge oor die openbare optrede van vroue nie.

Dat Paulus die grond van sy standpunt ontleen aan die skeppingsorde en die sondeval, en nie aan 'n gebruik van 'n tyd nie, word onderstreep deur 1 Tim. $2: 11-14$. Hier is twee argumente. Die eerste argument: Adam is eerste gemaak en hy is hoof van die vrou, soos Christus hoof van die gemeente is (Ef. 5: 23; 1 Pet. $3: 1)$. Die begrip hoof wees van beteken volgens Ridderbos geen fisiologiese of fisiese hoofskap nie, maar behels die gedagte „van het besloten zijn en het gerepresenteerd worden van de een in en door de ander, die door zijn aanvangspositie of door zijn eenmalig en beslissend optreden ten aanzien van de ander... een bepalend en dominerende plaats inneemt" (a.w.., p. 426 v.). Hoofwees wys dus op 'n posisie van regering en seggenskap. Die man se prioriteit word gegrond in die aanvangsrelasie ( 1 Kor. $11: 3,8$, 12). Dit is belangrik dat juis die begrippe soos hoof en liggaam die tiperende heilsleer, waarin vele in een begryp word, na vore bring (Ridderbos: a.w., p. 432). Die tweede argument gaan uit van die verleiding van Eva (1 Tim. 2 : 11-14), waardeur een van die gevolge van die sondeval is dat die vrou nie mag leer in die gemeentevergadering ( 1 Kor. $14: 35$ ) of oor die man lerend mag heers nie (1 Tim. $2: 11,12)$. Die verlossingswerk van Christus keer die orde nie om nie, net so $\mathrm{min}$ as wat dit die vrou verlos van die smart by die baar van kinders (1 Tim. $2: 15)$. (Vgl. J. D. Vorster: In die Skriflig, nr. 17, p. 36 e.v.).

Dit is duidelik dat die Skrif ten opsigte van die roeping tot optrede in die openbaar, veral optrede in verband met leer, heers, regeer, opsig hou, huisbestuur (vgl. 0.a. 1 Tim. 3), die vrou in die man begryp, maar in en deur die man laat verteenwoordig. Hoewel sy dus in Christus as mens volkome aan die man gelyk is (Gal. 3 : 28; Kol. $3: 11$ ) is daar 'n differensiasie in roeping na buite, ook t.o.v. die openbare optrede in die gemeente. Die Skrif weet van vroue wat hulle -mans na die kroon steek want Paulus en Petrus vermaan vroue om onderdanig te wees. As dit volgens die gewoonte van daardie tyd so vanselfsprekend was dat die vrou onderworpe moet wees, waarom kom afwyking so wyd voor? Die Skrif se dat die aanvangsrelasie so moet wees dat die man in sy huis en in die ge- 
meente (wat die huisgesin van God is, 1 Tim. $3: 5,15$ ) die beeld van Christus as die hoof (die vrou net so die beeld van die verloste gemeente as die liggaam) vertoon (Ef. $5: 22-23$ ) Hierdie simboliek sal tog sinloos wees indien die vrou die ..hoof" van die man moet wees soos Christus van sy gemeente.

2.4 Sommige het wel uit Titus $2: 3$, waar vroue vermaan word om leraresse van wat goed is te wees, afgelei dat hulle wel kon leer. Hierdie opvatting onderskei nie tussen die roeping van 'n mens, 'n man of ' $n$ vrou. in die amp van die gelowige en/of na binne (eie lewe, eje huis, gemeente) en in openbare amp na buite (die terreine waarop dic besonder ampte fungeer) nic.

Ridderbos wys ook op die skynbare teenstrydigheid van dic swyggobod (1 Kor $14: 34$ r) met die erkende gawe en vryheid vir die vrou om to bid en te profeteer in 1 Kor. 11. Hy los die teenstrydigheid op deur te wys dat die swyggebod op die vergadering van die gemeente slaan terwyl die bid en profeteer pneumatiese uitinge buite die offisiejle vergadering is (a.w., p. 516). Hoewel die argumente passend (prepon) en lelik (aischrom) in 1 Kor. 11 (n) 1 Kor. 14 vir Ridderbos on verwysing inhou na die gangbare matstawwe, gee hy egter toe dat die "dieper liggende moteef" gesoek moet word in ,de plaats die God aan den vrouw van den beginne heeft willen toekennen in haar verhouding tot de man..." (a. w., p. 517).

Ook beroepe op Rom. 16: 1, dat ousan diakonon tês ekklêsıs tes en kenchreais op 'n amptelike funksie dui, besit min bewyskrag. Diaken word nie hier as 'n tegniese term gebruik nie. Dit het die ruimer betekenis van dienares (vgl. diakonia in Rom. $12: 7,1$ Tess. $3: 2)$. Dr. N. J. Hommes sê: ,Wordt de naam van presbyter en episcopus noch in het N.T. noch in de oud-christelijke kerk ooit verbonden met een vrouw, geheel anders staat het met de naam diakonos". Hierdie stelling het geen afdoende Skrifgronde nie maar hoogstens 'n waarskynlikheid.

Ons verwys na die herhaalde voorkoms van argumente op sterkte van ,,may perhaps", .,could be an indication”, „no unequivocal answer" (G.E.S. 1968, p. 145), ,one may wonder" (p. 148), ens. Ons kan ons dus volkome vind in die kommentaar van Kommissie IV op die G.E.S. 1968 (Acta, art. 62) wat konkludeer dat Skrifbewyse nie gelewer is vir die aanname dal daar vroulike vertakkinge van enige van die erkende besondere ,ampte" was nie.

2.4 In verband met die diakens, wat klaarblyklik nie opsieners, herders, regeerders in die sin van die ouderlinge ( 1 Tim. $5: 17$; $3: 5$ ) was nie, word nogtans die kardinale vereiste gestel dat hulle hulle kinders en huise goed moet regeer (1 Tim. $3: 12$ ). Hieruit kan slegs afgelei word dat die apostel net aun manne dink as diakens. Tweedens moet hulle in hulle huise hulle as manne bewys het voordat hulle as diakens kan dien. Derdens is dit duidelik dat die diakens in hulle diens van huisbestuur, beheer, kortom in die versorging van die gemeente met stoflike gawes in diens van die koinonia, 
as voorganger (besondere amp) Christus verteenwoordig en dus as

'n man die relasie van hoof-tot-die-liggaam moet verbeeld.

2.5 Hoewel die Skrifgegewens dus telkens teruggryp na die skeppingsorde en aanvangrelasie in Gen. $2: 18$, moet in ag geneem word dat die sonde hierdie begrip verduister wanneer die vrou aan die man as sodanig gesubordineer word. Hierteenoor sou met reg na die vryheid en gelykheid en enersheid van man en vrou in Christus en voor God verwys kon word (Gal. $3: 28$; 1 Kor. $7: 4,13,14,39$; Gal. $5: 1,18$ ).

Indien egter Gen. 2 : 18 in die lig van die voorgaande Gen. 2 : $15-17$ en Gen. $1: 27,28$ besien word, beteken dit dat die vrou die man aanvul in die roeping van die Here. In die opsig is hulle één (Gen $2: 23,24$ ). Dit kan egter nie anders nie as dat in hierdie twee-eenheid (korporatiewe veel-in-een) een van hulle na vore moet tree as die korporatiewe verteenwoordiger van die gesin na buite en voor God. In hierdie relasie is die vrou aan die man ondergeskik, onderdanig. Die man is die verbondshoof in die gesin.

Die argumentasie in die rapport van die kommissie voor die G.E.S. 1968 (Acta, p. 148) lê die gedifferensieerde roeping van man en vrou een kant met ,be that as it may". Daarteenoor word die gangbare "in our time" en in die moderne "society" gestel. Vanweë die bevooroordeeldheid deur die gangbare ,in a time when the women in all fields of life, is acting as an ,equal' of the man and is in fact as such accepted by us Christians", word gesê dat die „subordination of woman in the Church" onhoudbaar geraak het. Dit word betwyiel of die ,dualism" tussen die vrou se posisie in moderne samelewing en die kerk die bedoeling van die Heilige Skrif is. Hierdie benadering openbaar baie duidelik dat die probleem oor die vrou in die amp van buite die Skrif ingedra is.

Is die moderne samelewing normatief vir die kerklike inrigting? Indien die Skrif vertolk moet word nadat ,ecclesiastical circumstances" in ,our time" vergelyk is met dié in die tyd van Paulus (Acta, G.E.S. 1968, p. 149) - word die kultuurhistoriese en ,kerklike omstandighede" normatief en dreig die gevaar dat elkeen die Skrif gaan „ontmitologiseer" soos hy dit goed dink.

\section{Enkele konklusies}

3.1 Hoewel die werk van die studiekommissies waardevolle resultate kan lewer, is dit basies ' $n$ onbegonne taak om die hele ampsleer in die gereformeerde kerke, wat deur die eeue in Konfessie, Kerkorde en Bevestigingsformuliere neergeslaan het, te misken, hersien of verdedig. Die bewyslas moet op diegene gerus het wat bepaalde afwykings van die Skrif meen op te merk. Die mandaat van die G.E.S. in 1963 verwys eensydig na die ,reformed practice of excluding women from the various ordained offices in the church" en gee opening vir bevooroordeelde uitgangspunte en argumente $e$ silentio. 
3.2 Die wese van die besondere ampte is geleë in God en Christus wat ' $n$ persoon as besondere instrument met die oog op verskillende dienste of funksies in die gemeente roep en aan die gemeente gee, volgens 'n ordelike grondplan vir organisasie. Die mees wesenlike karaktertrek van 'n besondere amp is daarom gelë̈ in die verteenwoordigende (van God en Christus) karakter daarvan.

3.3 Kragtens die instrumentele en verteenwoordigende karakter (vir God met die oog op die opbouing van die gemeente) is daar ' $n$ onlosmaaklike band tussen die persoon (as instrument) en die funksie of diens wat hy moet verrig. Daarom is roeping 'n essensiële karaktertrek van ' $n$ besondere diens. Die inwendige roeping (deur God persoonlik vir 'n bepaalde diens geroep) is primêr, apriories. Die uitwendige roeping en bevestiging deur die gemeente is sekondêr en aposteriories ten opsigte van die inwendige roeping. Dit is nietemin moontlik vir iemand om voor te gee dat hy 'n diens. kneg van Jesus Christus is.

3.4 Bevestiging of ordening, dit wil sê een of ander openbare seremoniële handeling en gebede tot die Here, is altyd gebruik om die persoon aan die diens waartoe hy in die gemeente geroep is en as sodanig aan die gemeente te verbind.

3.5 Die gangbare begrip ,.amp" en ,,ampsdraer" (samevattende noemer vir 'n verskeidenheid van gedifferensieerde dienste en gawes) gee nie die Skriftuurlike ampsleer suiwer weer nie. Die Nuwe Testament ken 'n groot verskeidenheid van gawes, dienste en bedieninge. Een persoon kan meer as een funksie vervul, mits die diens as 'n gawe van Christus in hom aan die gemeente voorgedra (bevestig) is. Omstandighede of persoonlike gawes of behoeftes plaas niemand tydelik of permanent in een of ander "diens" nie, tensy dat daar op die ordelike manier uitdrukking gegee is aan die goddelike sanksie sowel as die aanvaarding van die besondere roeping. Waar verskillende persone tot verskillende onderskeie dienste geroep word, kan niemand kragtens een diens bevoegdhede uitoefen wat tot ' $n$ ander diens behoort nie. Die beginsel moet die antwoord bepaal op die vraag van die kerke van Brasilië of 'n regeerouderling in kleiner kerke die seĕn in leesdienste kan uitspreek. Dit het ook alles te doen met vrae rondom die bevoegdheid van helpers om sakramente op die sendingveld te bedien.

3.6 Onder die gewone besondere dienste word dié van leraars (predikante-ouderlinge-opsieners), ouderlinge (opsieners, herders) en diakens verstaan. Dit is moontlik om vanuit genoemde leraars nog weer ' $n$ diens van leraars te onderskei wat leraars oplei $(2 \mathrm{Tim}$. $2: 2)$. Hiernaas kom gewone werkinge voor wat nie tot die „,besondere" dienste behoort nie, maar tog 'n besondere plek in die kerk kan hê, bv. voorsinger, ens.). Die belangrikste diens en werking is egter dié van elke gelowige. Elke „besondere" diens is gerig op die opbouing van die liggaam ran Christus deur die bediening aan elke lid daarvan te gee. 


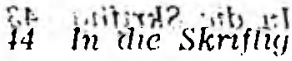

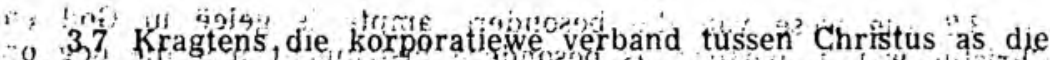
bedienaar, van sy gemeente, as die Hoóf-van-die-liggaam, "moet die besondere dienste wat Hy gebruik ook korporatiej beoordeel word die veelheid van die liggam is verteenwoordig' th die een. "Daarom is daar geen diskriminasie teen die lidmate, manne of 'vroue, Wat nie tot een of ander besondere bediening in die gemeente geroep word

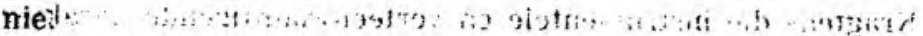

r: 3.8 Dit is:volgens die Skrif duidelik dat kragtens die aanvangsrelasie in die skeppingsorde, die: relasie van man en vrou na die sondeval, die aard van die man se roeping in die huis en liniêr daarmee sy roeping in die gemeente bepaal. Hierdie aard van die diens as sodanig word gekonstitueer deur die feit dat dit veral Christus by sy gemeente gerepresenteer op 'n wyse wat God gegee en - ingestel het en dat in alle gewone kerklike organisasie manne tot die besondere dienste geroep sal word...

3.9 Waar nodig kan egter ook vroue (naas hulle geroepenheid in die amp van die gelowige) onder leiding van die besondere ampte georganiseer word om dienste te lewer wat vir die gemeente nodig is. Hierdie dienste kan egter ne met dié van leraar, ouderling of diaken aangedui word nie, omdat dit nie die representatiewe en normatiewe karakter dra van die sogenaamde besondere dienste nie

Pretoria.

B. Spoelstra. 